\title{
PENDAMPINGAN MODEL PEMBELAJARAN INOVATIF DI SEKOLAH DASAR KECAMATAN MEDAN SELAYANG KOTA MEDAN
}

\author{
Nasrun $^{1 *}$, Faisal $^{1}$, Feriyansyah $^{1}$ \\ ${ }^{1}$ Fakultas Ilmu Pendidikan, Universitas Negeri Medan, Medan, Indonesia \\ *Penulis Korespondensi: nasrun.nst@gmail.com
}

\begin{abstract}
Abstrak
Program pendampingan ini bertujuan untuk meningkatkan kemampuan guru dalam mengintegrasikan model pembelajaran inovatif dalam pembelajaran di Sekolah Dasar (SD) Kecamatan Medan Selayang Kota Medan. Kemampuan mengintegrasikan model pembelajaran inovatif dalam pembelajaran memerlukan keterampilan khusus dalam penerapannya. Menyikapi hal itu, dilakukan pendampingan kepada para guru agar mampu mengintegrasikan model pembelajaran inovatif secara efektif sesuai tuntutan pembelajaran di SD. Metode pendampingan dilakukan melalui beberapa tahap kegiatan, antara lain: persiapan, pelaksanaan, evaluasi dan refleksi, serta tindak lanjut. Luaran yang dihasilkan melalui program pendampingan antara lain: buku panduan model pembelajaran inovatif di SD, guru model pengintegrasian model pembelajaran inovatif, dan artikel ilmiah yang dipublikasikan pada jurnal berISSN online. Hasil program pengabdian menunjukkan bahwa meningkatnya kemampuan guru dalam mengintegrasikan model pembelajaran inovatif dalam pembelajaran di SD Kecamatan Medan Selayang Kota Medan. Dengan demikian, pendampingan yang dilakukan telah berjalan secara efektif dan sesuai dengan hasil yang diharapkan.
\end{abstract}

Kata kunci: model pembelajaran inovatif, guru model, SD

\begin{abstract}
This mentoring program aims to improve the ability of teachers in integrating innovative learning models in learning in elementary school (SD) Kecamatan Medan Selayang Medan. The ability to integrate innovative learning models in learning requires specific skills in their application. Responding to that, done by the teachers to be able to integrate innovative learning model effectively according to the demand of learning in elementary school. Methods of assistance are conducted through several stages of activity, including: preparation, implementation, evaluation and reflection, and follow-up. Outcomes generated through the mentoring program include: an innovative learning model guidebook in elementary school, teacher model of integrating innovative learning model, and scientific article published in ISSN online journal. The results of the devotion program indicate that the increasing ability of teachers in integrating innovative learning models in learning in SD Medan Selayang Sub-district Medan. Thus, the assistance performed has been run effectively and in accordance with the expected results.
\end{abstract}

Keywords: innovative learning model, model teacher, elementary school

\section{PENDAHULUAN}

Salah satu penentu kesuksesan proses pembelajaran di Sekolah Dasar (SD) adalah kemampuan guru dalam memilih dan menggunakan model pembelajaran inovatif. Di dalam literatur ditemukan berbagai macam model pembelajaran. Untuk memilih/menentukan model pembelajaran yang sesuai untuk siswa pada jenjang pendidikan tertentu, perlu disesuaikan dengan tingkat perkembangan siswa dan prinsip-prinsip belajar (seperti kecepatan belajar, motivasi, minat, keaktivan siswa, dan umpan balik/penguatan), serta yang tidak kalah pentingnya adalah bahwa pemilihan model pembelajaran seyogyanya berbasis pada pendekatan pembelajaran yang berorientasi pada konsep pembelajaran mutakhir.

Model pembelajaran adalah suatu perencanaan yang digunakan sebagai pedoman dalam merencanakan pembelajaran di kelas untuk menentukan perangkatperangkat pembelajaran (Trianto, 2007:5). Pendapat lain juga menjelaskan bahwa model sebagai kerangka konseptual yang digunakan sebagai pedoman dalam melakukan suatu kegiatan (Wena, 2009:72). Berdasarkan pendapat tersebut menjelaskan bahwa model pembelajaran merupakan kerangka konseptual yang melukiskan prosedur yang sistematis dalam 
mengorganisasikan pengalaman belajar untuk mencapai tujuan belajar tertentu.

Model pembelajaran menggambarkan tingkat terluas dari praktek pembelajaran dan berisikan orientasi filosofi pembelajaran, yang digunakan untuk menyeleksi dan menyusun strategi pengajaran, metode, keterampilan, dan aktivitas pebelajar untuk memberikan tekanan pada salah satu bagian pembelajaran (Uno, 2007:83). Dengan demikian, dapat disimpulkan bahwa model pembelajaran dapat diartikan sebagai suatu pola yang digunakan dalam menyusun kurikulum, merancang dan menyampaikan materi, mengorganisasikan pembelajar, dan memilih media dan metode dalam suatu kondisi pembelajaran.

Saat ini, pelaksanaan kegiatan pembelajaran di SD masih menggunakan 2 bentuk kurikulum, yaitu kurikulum KTSP dan kurikulum 2013. Perbedaan mendasar pada kedua kurikulum ini adalah pendekatan pembelajaran yang digunakan. Pada kurikulum KTSP, pendekatan pembelajaran untuk kelas rendah dilakukan dengan pendekatan tematik dan di kelas tinggi dilakukan dengan pendekatan bidang studi. Sedangkan pada kurikulum 2013 dilakukan dengan pendekatan tematik untuk seluruh kelas, mulai dari kelas I s.d kelas VI SD. Suksesnya proses pembelajaran dilaksanakan, baik pendekatan tematik maupun pendekatan bidang studi ditentukan dengan variatif cara mengajar yang digunakan atau model pembelajaran yang digunakan.

Berdasarkan hasil wawancara dan observasi di SD AlIkhlas Kec. Medan Selayang dan SD Darma Wanita Kec. Medan Selayang diperoleh fakta bahwa pembelajaran di kelas belum berjalan secara efektif dan belum mencapai hasil yang maksimal. Beberapa hal yang ditemukan antara lain: (1) pembelajaran masih monoton sehingga siswa terlihat bosan dalam pembelajaran, (2) RPP yang dirumuskan belum menunjukkan berorientasi pada aktivitas, (3) penilaian yang dilakukan belum berorientasi pada penilaian otentik di SD.

Paradigma pembelajaran seperti di atas, adanya indikasi bahwa pembelajaran aktif yang berbasis aktivitas belum berjalan seperti yang diharapkan. Hal ini terjadi karena belum mampunya guru merancang perangkat pembelajaran yang berorientasi pada model pembelajaran tertentu, melaksanakan proses pembelajaran dengan menggunakan model pembelajaran inovatif, dan melakukan penilaian otentik dalam pembelajaran. Dengan demikian, pendampingan penggunaan model pembelajaran inovatif mutlak diperlukan sebagai upaya peningkatan kompetensi guru terutama yang berkaitan dengan kemampuan merancang, melaksanakan proses pembelajaran, dan menilai secara otentik setiap pembelajaran di SD.
2. METODE PELAKSANAAN KEGIATAN 2.1 Metode Pelaksanaan

Metode pelaksanaan kegiatan dilakukan ke dalam beberapa tahap, antara lain:

\section{1) Persiapan}

Pada tahap persiapan, terdapat beberapa kegiatan, di antaranya: (a) sosialisasi program pengabdian kepada sekolah mitra, (b) observasi dan wawancara untuk analisis masalah, diskusi alternatif pemecahan masalah, (c) menentukan jadwal kegiatan, (d) membangun komitmen bersama dengan sekolah mitra, dan (e) menyiapkan sarana dan prasarana pendukung terlaksananya kegiatan pengabdian.

2) Pelaksanaan

Pada tahap pelaksanakan, dilakukan kegiatan pengabdian terkait dengan permasalahan yang dihadapi sekolah mitra, meliputi: (a) pelatihan dalam bentuk pendalaman materi tentang modelmodel pembelajaran inovatif di SD, (b) pelatihan dan workshop perumusan RPP yang berorientasi pada model-model pembelajaran inovatif, dan (c) pelatihan dan workshop pelaksanaan pembelajaran yang berorientasi pada model-model pembelajaran inovatif. Hingga pada akhirnya diperoleh guru model yang mampu mengintegrasikan modelmodel pembelajaran inovatif di SD secara efektif.

3) Evaluasi dan Refleksi

Tahap evaluasi dan refleksi merupakan penilaian terhadap keberhasilan program pengabdian yang telah dilaksanakan. Berdasarkan hasil evaluasi dan refleksi akan diperoleh gambaran terkait dengan tingkat capaian keberhasilan dan faktor kendala jika program pengabdian yang dilakukan belum berhasil sesuai dengan yang diharapkan.

\section{4) Tindak Lanjut}

Tindak lanjut merupakan feedback dari hasil evaluasi program pengabdian. Tindak lanjut mengarahkan keberlanjutan program atau peningkatan program yang dapat dilakukan pada masa yang akan datang. Jika program pendampingan belum berhasil, dilakukan usaha perbaikan berdasarkan telaah hasil evaluasi sebelumnya.

\subsection{Metode Pendekatan}

Metode pendekatan disesuaikan dengan permasalahan dan terget capaian setiap kegiatan. Beberapa metode yang dapat digunakan dalam pengabdian ini antara lain: pelatihan, pendampingan, simulasi, wawancara, catatan lapangan, observasi, dan kerjasama. Setiap metode diaplikasikan berdasarkan tujuan kegiatan yang ingin dicapai. Untuk lebih jelasnya, dapat dilihat pada tabel berikut.

Tabel 1. Metode Pendekatan Pelaksanaan Kegiatan

\begin{tabular}{|c|l|l|l|}
\hline No & \multicolumn{1}{|c|}{ Kegiatan } & Jenis Luaran & \multicolumn{1}{|c|}{$\begin{array}{c}\text { Metode } \\
\text { Pendekatan }\end{array}$} \\
\hline 1. & $\begin{array}{l}\text { Pelatihan } \\
\text { peningkatan } \\
\text { pemahaman } \\
\text { tentang model- } \\
\text { model }\end{array}$ & $\begin{array}{l}\text { Buku } \\
\text { pedoman } \\
\text { tentang } \\
\text { model-model }\end{array}$ & $\begin{array}{l}\text { Pelatihan, } \\
\text { observasi, } \\
\text { catatan } \\
\text { lapangan, dan } \\
\text { kerja sama }\end{array}$ \\
\hline
\end{tabular}




\begin{tabular}{|c|l|l|l|}
\hline & $\begin{array}{l}\text { pembelajaran } \\
\text { inovatif }\end{array}$ & $\begin{array}{l}\text { pembelajaran } \\
\text { inovatif }\end{array}$ & \\
\hline 2. & $\begin{array}{l}\text { Pelatihan dan } \\
\text { workshop } \\
\text { peningkatan } \\
\text { kemampuan } \\
\text { merumuskan RPP }\end{array}$ & $\begin{array}{l}\text { Buku } \\
\text { panduan dan } \\
\text { contoh RPP }\end{array}$ & $\begin{array}{l}\text { Pelatihan, } \\
\text { pendampingan, } \\
\text { wawancara, dan } \\
\text { observasi }\end{array}$ \\
\hline 3. & $\begin{array}{l}\text { Pelatihan dan } \\
\text { simulasi } \\
\text { pelaksanaan } \\
\text { pembelajaran } \\
\text { yang berorientasi } \\
\text { pada model-model } \\
\text { pembelajaran } \\
\text { inovatif di SD }\end{array}$ & $\begin{array}{l}\text { Guru model } \\
\text { dalam bentuk } \\
\text { CD } \\
\text { pembelajaran }\end{array}$ & $\begin{array}{l}\text { Pelatihan, } \\
\text { pendampingan, } \\
\text { simulasi, } \\
\text { observasi, } \\
\text { wawancara, } \\
\text { catatan } \\
\text { lapangan, dan } \\
\text { kerjasama }\end{array}$ \\
\hline
\end{tabular}

\subsection{Evaluasi Pelaksanaan Program dan Keberlanjutan Program}

Evaluasi program dilakukan mulai dari perencanaan, pelaksanaan, dan hasil setiap kegiatan. Evaluasi yang dilakukan tidak hanya pada hasil, tetapi proses pelaksanaan kegiatan. Dengan demikian, kekurangan atau kendala yang diperoleh pada setiap pelaksanaan program dapat diidentifikasi dengan mudah dan dapat dicarikan solusi secara cepat dan tepat sesuai dengan permasalahan yang ditemukan.

Setelah masalah yang ditemukan dapat diatasi secara efektif, barulah kemudian dilaksanakan program atau kegiatan selanjutnya. Hal inilah yang dikatakan dengan keberlanjutan program. Program akan berlanjut apabila satu kegiatan utama dapat diselesaikan dengan baik. Namun, jika terdapat kendala dalam melaksanakan program utama, program selanjutnya belum dapat dilanjutkan.

Secara sederhana proses pelaksanaan evaluasi program dan keberlanjutan program di lapangan dapat dilihat pada gamar 1 berikut.

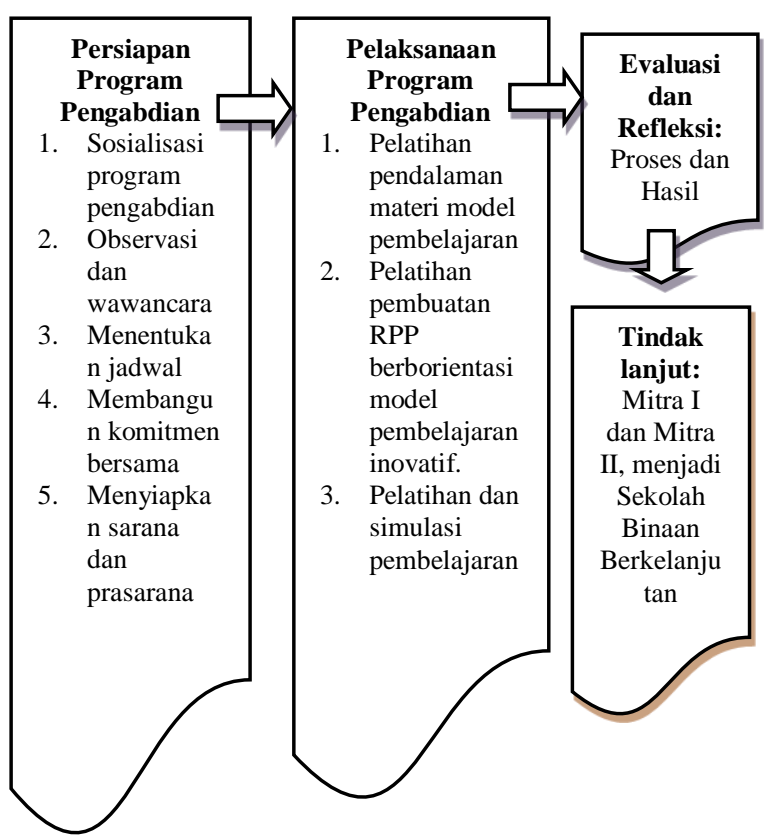

Gambar 1. Evaluasi Pelaksanaan dan Keberlanjutan Program

\section{HASIL KEGIATAN DAN PEMBAHASAN}

\subsection{Hasil Kegiatan}

Hasil program pengabdian dapat dijabarkan melalui beberapa kegiatan, antara lain: persiapan, pelaksanaan, evaluasi dan refleksi, dan tindak lanjut. Untuk lebih jelasnya dapat dijelaskan sebagai berikut:

\section{1) Persiapan}

Pada tahap persiapan program pendampingan, dilakukan beberapa kegiatan, di antaranya: (a) membangun komitmen bersama dengan mitra, (b) menyiapkan buku panduan pengintegrasian model pembelajaran inovatif di SD, (c) contoh Rencana pelaksanaan Pembelajaran (RPP) pengintegrasian model pembelajaran inovatif dalam pembelajaran, (d) panduan penilaian otentik, dan (e) peralatan pendukung lainnya, seperti: infocus, loudspeaker, dan soundsystem.

\section{2) Pelaksanaan}

Pendampingan dilaksanakan pada tanggal 14 s.d 16 Agustus 2017 di SD Al-Ikhlas Kec. Medan Selayang Kota Medan. Pada tahap pelaksanaan, dilakukan tiga tahap kegiatan, yaitu: pendalaman materi tentang model pembelajaran inovatif di SD, merancang RPP dan penilaian, dan simulasi pengintegrasian model pembelajaran inovatif dalam pembelajaran di SD. Untuk lebih jelasnya dijabarkan sebagai berikut:

\section{a. Pendalaman Materi tentang Model}

Pembelajaran Inovatif

Pendalaman materi tentang model pembelajaran inovatif dilaksanakan pada tanggal 14 Agustus 2017. Materi yang dipaparkan ketika pendalaman materi antara lain: (1) hakikat model pembelajaran, (2) macam-macam model pembelajaran inovatif di SD meliputi: pendekatan saintifik, model Problem Based Learning (PBL), model Project Based Learning (PjBL), dan model Discovery Learning (DL), (3) panduan perumusan RPP, dan (4) panduan penilaian otentik di SD. Berdasarkan hasil analisis pemahaman guru terhadap model-model pembelajaran inovatif diperoleh gambaran bahwa hampir $90 \%$ peserta memahami pengintegrasian model pembelajaran inovatif dalam pembelajaran di SD.

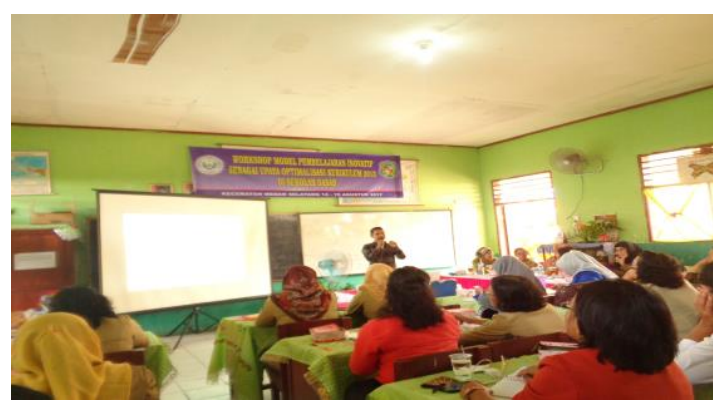



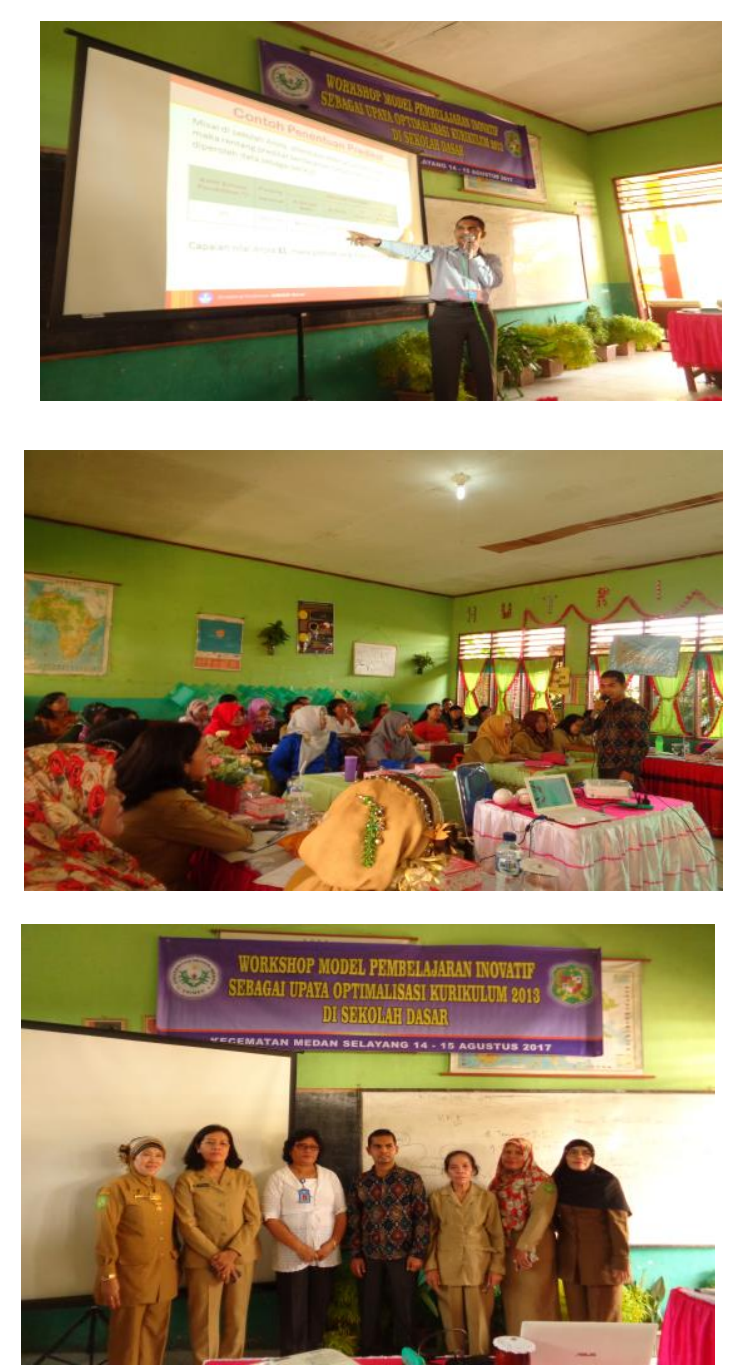

Gambar 2. Pendalaman Materi tentang Model Pembelajaran Inovatif

\section{b. Perumusan RPP dan Penilaian Otentik}

RPP yang dirumuskan merupakan RPP pengintegrasian model pembelajaran inovatif di SD. Para guru dilatih dan dibimbing terkait dengan komponen RPP yang ideal dan cara mengintegrasikan model pembelajaran inovatif di dalamnya. Setelah mampu merumuskan RPP sesuai dengan komponen dan konten yang terkandung di dalamnya dilanjutkan dengan perumusan penilaian otentik. Penilaian otentik dimulai dari pemaparan materi tentang HOTS (High Order Thinking Skills), penilaian sikap, keterampilan, dan pengetahuan secara otentik.

Berdasarkan hasil analisis terhadap rumusan RPP dan penilaian otentik diperoleh gambaran bahwa tingkat ketercapaian mencapai $87 \%$ dengan kategori Sangat Baik (SB). Secara sederhana, kegiatan perumusan RPP dan penilaian otentik dapat dilihat pada gambar 3 berikut.
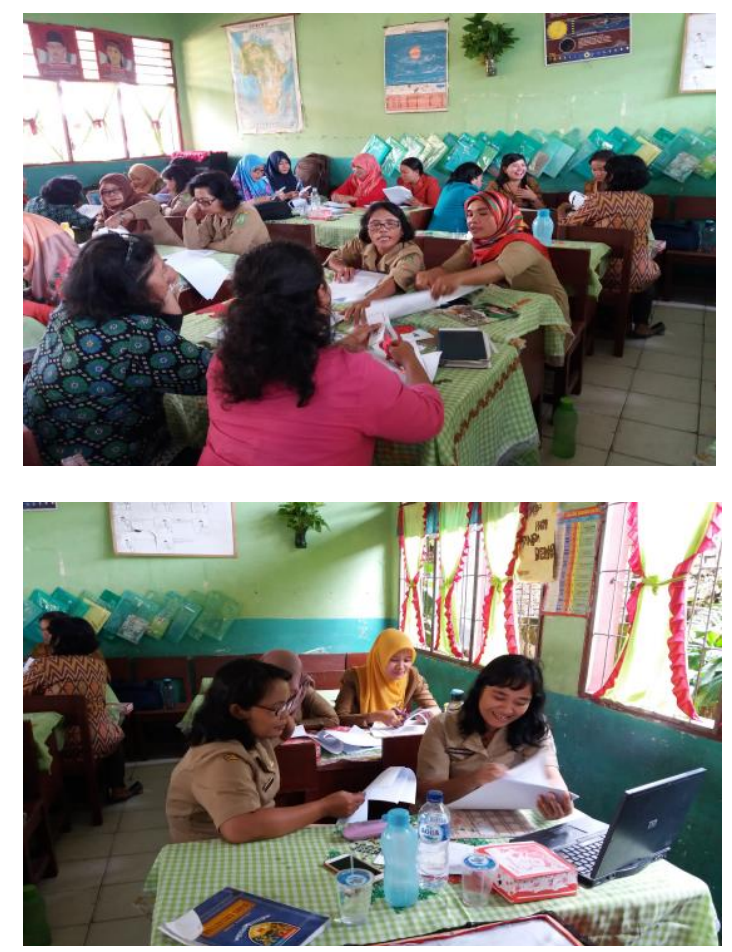

Gambar 3. Perumusan RPP dan Penilaian Otentik

\section{c. Simulasi Pembelajaran}

Simulasi pembelajaran dilaksanakan setelah RPP dan bentuk penilaian otentik selesai dirumuskan. Simulasi pembelajaran ini berguna untuk memperoleh masukan dan saran terhadap proses pembelajaran yang telah dilaksanakan. Melalui masukan dan saran yang diberikan akan diperoleh guru model terkait dengan pengintegrasian model pembelajaran inovatif dalam pembelajaran di SD. Kegiatan simulasi dilakukan secara berkelompok. Perwakilan kelompok akan mensimulasikan RPP dan penilaian otentik yang dirumuskannya. Jika dianalisis penampilan simulasi kelompok diperoleh tingkat keberhasilan mencapai $85 \%$ dengan kategori Sangat Baik (SB). Secara sederhana, kegiatan simulasi pembelajaran dapat dilihat pada gambar 4 berikut.

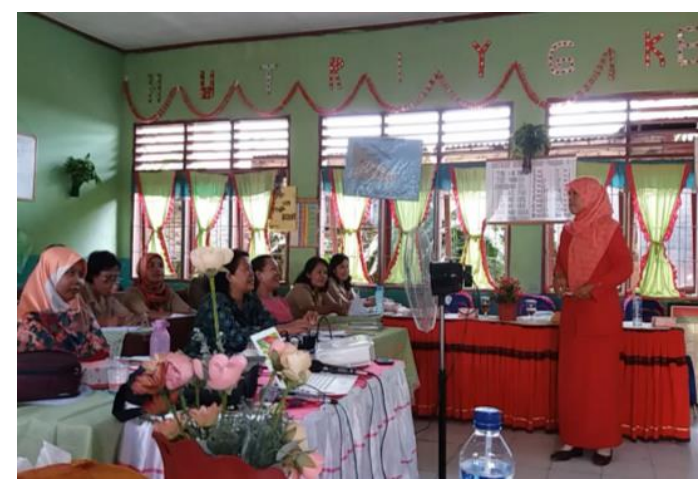



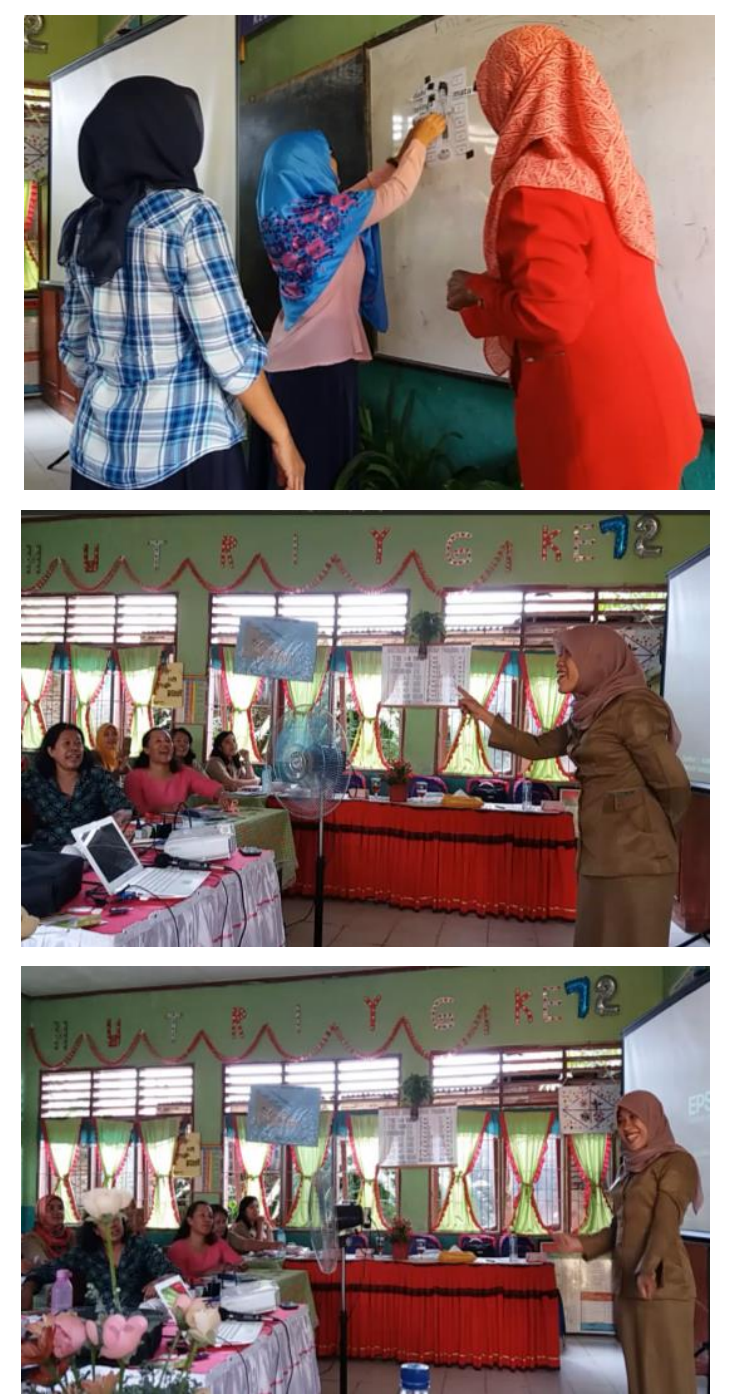

Gambar 5. Guru Model (Simulasi Pembelajaran)

\section{3) Evaluasi dan Refleksi}

Tahap evaluasi dan refleksi dilakukan untuk mengukur tingkat keberhasilan program pendampingan yang telah dilakukan. Berdasarkan hasil analisis, tingkat ketercapaian program pendampingan dapat dilihat pada tabel 2 berikut.

Tabel 2. Tingkat Keteracapaian Program Pendampingan

\begin{tabular}{|c|l|c|c|}
\hline No & \multicolumn{1}{|c|}{ Kegiatan } & Persentase & Kualifikasi \\
\hline 1 & $\begin{array}{l}\text { Pendalaman materi } \\
\text { tentang model } \\
\text { pembelajaran inovatif }\end{array}$ & $90 \%$ & SB \\
\hline 2 & $\begin{array}{l}\text { Perumusan RPP dan } \\
\text { penilaian otentik }\end{array}$ & $87 \%$ & SB \\
\hline 3 & Simulasi pembelajaran & $85 \%$ & SB \\
\hline
\end{tabular}

Mengacu pada tabel di atas, tingkat ketercapaian program pendampingan tergolong tinggi dengan kualifikasi sangat baik. Meskipun demikian, terdapat beberapa kelemahan yang ditemui berdasarkan program pendampingan, antara lain:

a) Masih banyaknya guru yang kurang mampu menggunakan IT sehingga kurang mampu melakukan proses pembelajaran yang terintegrasi dengan model pembelajaran inovatif dan berbasis multimedia.

b) Ada beberapa guru kurang maksimal dalam menggunakan media pembelajaran. Media pembelajaran kurang digali lebih mendalam sehingga minim informasi. Dengan demikian, pemanfaatan media pembelajaran kurang dirasakan sebagai alat bantu yang efektif dalam proses pembelajaran.

\section{4) Tindak Lanjut}

Berdasarkan evaluasi dan refleksi yang dikemukakan perlu dilakukan tindak lanjut pada masa yang akan datang, di antaranya:

a) Pendampingan berkelanjutan tentang pembelajaran inovatif berbasis multimedia, sehingga keterampilan guru dalam menggunakan IT dapat ditingkatkan.

b) Pendampingan berkelanjutan tentang pemanfaatan media dalam pembelajaran sehingga peran media dapat dirasakan manfaatnya sebagai penunjang proses pembelajaran efektif di kelas.

\subsection{Pembahasan}

Program pengabdian berupa pendampingan model pembelajaran inovatif di SD Kec. Medan Selayang Kota Medan telah berhasil dilaksanakan. Para guru telah mampu mengintegrasikan model-model pembelajaran inovatif dalam pembelajaran di SD. Firman (2000:56) menjelaskan bahwa keberhasilan sebuah program ditandai dengan ciri-ciri sebagai berikut: (a) berhasil mengantarkan peserta mencapai tujuan-tujuan instruksional yang telah ditetapkan, (b) memberikan pengalaman belajar yang atraktif, melibatkan peserta secara aktif sehingga menunjang pencapaian tujuan instruksional, dan (c) memiliki sarana-sarana yang menunjang proses pembelajaran. Selain itu, dijelaskan juga bahwa keberhasilan program ditandai dengan persentase keberhasilan minimal $\geq 75 \%$ pada kategori baik.

Berpedoman pada pendapat di atas, tingkat ketercapaian program pendampingan dapat dijabarkan sebagai berikut.

\section{1) Pendalaman Materi tentang Model} Pembelajaran Inovatif

Pendalaman materi tentang model pembelajaran inovatif mencapai tujuan yang diharapkan. Para guru telah paham tentang pengertian model pembelajaran inovatif, macam-macam model pembelajaran inovatif di SD, dan cara mengintegrasikannya ke dalam pembelajaran. Tingkat ketercapaian mencapai $90 \%$ dengan kategori Sangat Baik (SB). Artinya, pemaparan materi tentang model pembelajaran inovatif dapat dilakukan dengan baik dan mencapai target sasaran.

\section{2) Perumusan RPP dan Penilaian Otentik}

Perumusan RPP dan penilaian otentik juga berjalan sesuai harapan. Para guru mampu merumuskan 
RPP dan penilaian otentik secara efektif. RPP yang dirumuskan telah mencerminkan pengintegrasian model pembelajaran inovatif di dalamnya. Demikian juga halnya dengan penilaian otentik, telah dirumuskan dan disimulasikan dalam pembelajaran dengan baik. Tingkat keberhasilan pelaksanaan kegiatan mencapai $87 \%$ dengan kategori (Sangat Baik). Artinya, secara umum perumusan RPP dan penilaian otentik dapat terlaksana dengan baik dan sesuai harapan.

\section{3) Simulasi Pembelajaran}

Simulasi pembelajaran mencerminkan pembelajaran yang mengintegrasikan model pembelajaran inovatif di dalamnya. Hal ini mencerminkan bahwa guru telah paham dalam mengintegrasikan model pembelajaran inovatif dalam pembelajaran. Tingkat ketercapaian program ketika simulasi pembelajaran mencapai 85\% dengan kategori Sangat Baik (SB). Artinya, para guru sangat baik dalam melakukan simulasi pembelajaran terkait dengan pengintegrasian model pembelajaran inovatif dalam pembelajaran di SD.

Berdasarkan ketiga kegiatan yang dikemukakan di atas, secara sederhana tingkat keberhasilan program pendampingan dapat digambarkan pada gambar 6 berikut.

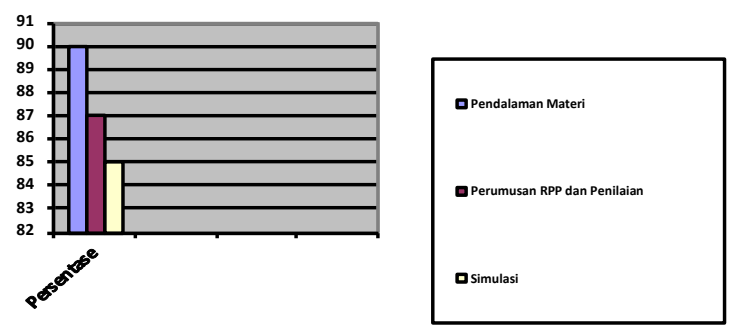

Gambar 6. Tingkat Ketercapaian Program Pendampingan

\section{LUARAN YANG DICAPAI}

Jenis luaran yang dihasilkan berdasarkan kegiatan yang dilakukan antara lain:

1) Buku panduan model-model pembelajaran inovatif di SD yang berisi: (1) hakikat model pembelajaran, (2) model-model pembelajaran inovatif di SD, (3) contoh RPP penerapan model pembelajaran inovatif dalam pembelajaran, dan (4) penilaian otentik di SD.

2) Guru model penggunaan model-model pembelajaran inovatif di SD yang tergambar melalui video pembelajaran sehingga dapat dijadikan acuan bagi guru-guru yang lain.

3) Artikel ilmiah yang dipublikasikan pada jurnal nasional ber-ISSN Online.

\section{SIMPULAN}

Pendampingan model pembelajaran inovatif bagi guru di SD Kec. Medan Selayang Kota Medan berjalan secara efektif sesuai harapan. Para guru telah paham bagaimana cara mengintegrasikan model pembelajaran inovatif dalam pembelajaran di SD. Hal ini tergambar melalui kemampuan guru dalam merumuskan RPP dan penilaian serta mensimulasikan pembelajaran yang terintegrasi dengan model pembelajaran inovatif. Walaupun demikian, terdapat kelemahan yang ditemukan berdasarkan program pendampingan terutama dalam hal keterampilan menggunakan IT dan kurang maksimalnya pemanfaatan media pembelajaran. Dengan demikian, perlu dilakukan pendampingan lebih lanjut sebagai upaya mencapai proses pembelajaran yang efektif di masa mendatang.

\section{DAFTAR PUSTAKA}

Firman, Harry. 2000. Penilaian Hasil Belajar dalam Pengajaran. Bandung: FMIPA UPI

Trianto. 2007. Model Pembelajaran Terpadu dalam Teori dan Praktek. Jakarta: Prestasi Pustaka.

Uno, Hamzah B. 2007. Model Pembelajaran Menciptakan Proses Belajar Mengajar yang Kreatif dan Efektif. Jakarta: Bumi Aksara.

Wena, Made. 2009. Strategi Pembelajaran Inovatif Kontemporer suatu Tinjauan Konseptual Operasional. Jakarta: Bumi Aksara. 